\title{
Penerapan Pasal 33 Ayat (2) Undang-Undang Nomor 7 Tahun 2011 Tentang Mata Uang di Maluku
}

\section{Fikry Latukau}

Dosen Program Studi Hukum Pidana Islam Fakultas Syariah dan Ekonomi Islam IAIN Ambon, Email: fikry18001@mail.unpad.ac.id

\section{Deassy J.A. Hehanussa}

Dosen Fakultas Hukum Universitas Pattimura Ambon, Email: deassyhehanussa@gmail.com

\section{Erwin Ubwarin}

Dosen Fakultas Hukum Universitas Pattimura Ambon, Email: eubwarin@gmail.com

\begin{abstract}
Currency rejection is very common, especially in Ambon City, Maluku Province, and if the community does not want to accept or reject the coins, then there will be a violation of the law in accordance with article 33 paragraph (2). In this study the method used is empirical juridical which in other words is a type of sociology legal research and can also be referred to as field research, which examines the applicable legal provisions and what happens in reality in society. Legal tender in principle is a legal provision that states that a payment instrument can be generally accepted as a legal tender and cannot be refused as a means of payment. In dealing with problems in the enforcement of criminal law that occurs in society can be done in a penal (criminal law) and non-criminal (without using criminal law). To prevent the practice of denial of payment in rupiah, in criminal law there are two ways or efforts to the police and Bank Indonesia Maluku representative offices to deal with crime or violations, namely preventive efforts (prevent before the occurrence of crime) and repressive efforts (efforts as young as crime) ).
\end{abstract}

Keywords: Application of article; Currency; Molucas

\section{PENDAHULUAN}

Tanah air Indonesia dikaruniai Tuhan Yang Maha Esa dengan wilayah yang sangat luas dengan banyaknya pulau-pulau di dalamnya. Namun demikian di Indonesia masih ada beberapa wilayah yang tertinggal dan yang termiskin. Maluku merupakan salah satu provinsi termiskin ke empat di Indonesia. Padahal pemerintah telah membuat berbagai hal demi kemajuan daerah ini. Disetiap Negara mempunyai dasar hukum yang mengatur semua yang terjadi di Negara tersebut begitupun di Indonesia, semua persoalan diatur dalam Undang-undang.

Dalam Undang-undang Dasar Negara Republik Indonesia Tahun 1945 pasal 1 ayat (3) menjelaskan "Negara Indonesia adalah Negara Hukum". Hukum bekerja dengan memberikan batasan-batasan mengenai apa yang boleh dilakukan dan apa yang tidak boleh dilakukan, maka dari itu terdapat sanksi bagi pelanggar batasan-batasan tersebut. Hukum seyogyanya dibuat untuk ditaati, akan tetapi dalam realitanya masih banyak

\footnotetext{
${ }^{1}$ Agus Pamungkas Amandemen UUD 1945, Cetakan Pertama, Buku Pintar 2011. hal 8.
} 
masyarakat yang melanggar peraturan sehinga mengakibatkan gangguan keamanan dan ketertiban umum. Aktivitas hukum sering dilakukan dalam kehidupan sehari-hari. Sebuah tindakan disebut sebagai perbuatan hukum jika mempunyai akibat yang dapat dipertanggung jawabkan secara hukum atau diakui oleh negara. Hukum itu sendiri adalah aturan yang secara resmi telah disahkan oleh pemerintah melalui lembaga atau instansi hukum.

Hukum menciptakan ketertiban, keamanan, keadilan serta kesejahteraan bagi masyarakat, keberadaan hukum dapat dikatakan sebagai kebutuhan masyarakat, baik kebutuhan secara individu maupun ketika dalam melakukan interaksi dengan orang lain maka hukum adalah senjata paling ampuh untuk mengatur kehidupan manusia dalam segala hal.

Hukum sering kali dikenal sebagai suatu gejala sosial yang sangat rumit. Semula pandangan tersebut dilontantarkan oleh orang-orang yang memang awam akan hukum, dalam arti tidak pernah mengalami pendidikan hukum. Peristiwa-peristiwa sosial tersebut senantiasa menyangkut kejadian-kejadian yang berkaitan dengan hubungan antara manusia pribadi dengan kelompok manusia, atau antara suatu kelompok tertentu dengan kelompok lainnya. ${ }^{2}$ Hukum dapat juga dikatakan sebagai rules of conduct, for men behavior in a society (aturan tingkah laku manusia di masyarakat tertentu). Dengan demikian dapat dikatakan hukum menghilangkan ketidakpastian, hukum memberikan jaminan bagi terjadinya perubahan sosial yang tertib. A.G Peter menyebutkan paling tidak ada 3 (tiga) perspektif dari fungsi hukum yaitu perspektif social control, social control engineering, dan emansipatve.

Dalam kerangka perspektif social control, fungsi utama dari sistem hukum bersifat intergratif. Hukum dimaksudkan untuk mengatur dan memelihara regulitas sosial dalam suatu sistem sosial, tanpa hukum masyarakat akan menjadi homo homini lupus (manusia yang satu menjadi serigala bagi manusia lainnya), tiada masyarakat yang bisa hidup lama tanpa control sosial dari hukum sebagai sarananya.

Untuk dapat menjalankan fungsi kontol sosial tersebut, Parsons mengemukakan empat prasyarat fungsional dari suatu hukum yaitu :

1. Masalah dasar legitimasi, yakni ideologi yang menjaadi dasar penataan aturan hukum

2. Masalah hak dan kewajiban masyarakat yang menjadi sasaran regulasi hukum berserta proses hukumnya.

3. Masalah sanksi dan lembaga yang menerapkan sanksi tersebut, dan masalah kewenangan penegakan aturan hukum. ${ }^{3}$

Banyak sekali terjadi pelanggaran di Indonesia yang semuanya itu telah di atur dan diproses sesuai hukum yang berlaku. Salah satu bentuk pelanggaran yang saat ini terjadi di Indonesia, khususnya di Maluku yaitu penolakan uang koin rupiah dari pecahan 200 rupiah sampai dengan pecahan yang terendah. Padahal sampai saat ini belum ada larangan untuk tidak menggunakan uang koin pecahan 200 rupiah sampai dengan pecahan terendah dari pemerintah dalam hal ini Bank Indonesia yang mempunyai wewenang penuh menetapkan penggunaan alat pembayaran sesuai dengan Undang-

\footnotetext{
${ }^{2}$ Soerjono Soekanto, Efektivikasi Hukum dan Peranan Sanksi, Cetakan pertama, Remaja Karya CV Bandung 1985. hal 1.

${ }^{3}$ Edi Setiadi Dan Rena Yulia, Hukum Pidana Ekonomi, Edisi Pertama, Cetakan Pertama, 2010. hal 1 dan 2 .
} 
undang No. 23 Tahun 1999 Tentang Bank Indonesia Pasal 15 Ayat (1) yang menyebutkan :

Dalam rangka mengatur dan menjaga kelancaran sistem pembayaran sebagaimana dimaksud dalam pasal 8 hurup b, Bank Indonesia berwenang :

a. Melaksanakan dan memberikan persetujuan dan izin atas penyelenggaraan jasa sistem pembayaran;

b. Mewajibkan penyelenggaraan jasa sistem pembayaran untuk menyampaikan laporan tentang kegiatannya;

c. Menetapkan penggunaan alat pembayaran.

Pelanggaran ini sangat sering ditemui terutama di Kota Ambon yang merupakan ibu kota dari Provinsi Maluku yang menjadi pusat perdagangan dan jasa, pusat kegiatan pemerintahan, jasa angkutan barang dan penumpang, pelayanan pendidikan dan pelayanan kesehatan, serta Kota Ambon yang merupakan kota bisnis dan juga sebagai salah satu tujuan objek wisata di Indonesia bagian timur, maka dari itu banyak orang datang maupun mencari pekerjaan di Kota Ambon, sehingga kota ini semakin padat dan ramai, oleh karena itu tidak menutup kemungkinan akan terjadi transaksi dengan menggunakan uang koin, dan apabila masyarakat tidak mau menerima atau menolak uang pecahan koin tersebut, maka akan terjadi pelanggaran hukum sesuai dengan Pasal 33 ayat (2) "bahwa :

Setiap orang dilarang menolak untuk menerima Rupiah yang penyerahannya dimaksudkan sebagai pembayaran atau untuk menyelesaikan kewajiban yang harus dipenuhi dengan Rupiah dan/atau untuk transaksi keuangan lainnya di Wilayah Negara Kesatuan Republik Indonesia, kecuali karena terdapat keraguan atas keaslian Rupiah sebagaimana dimaksud dalam Pasal 23 dipidana dengan pidana kurungan paling lama 1 (satu) tahun dan pidana denda paling banyak Rp200.000.000,00 (dua ratus juta rupiah).

Tetapi hingga sekarang masih terlihat bahkan masih banyak orang yang menolak uang rupiah pecahan koin tersebut disebabkan oleh beberapa faktor antara lain, belum maksimalnya penegak hukum dalam menjalankan undang - undang ketentuan pidana tersebut, dan masih rendahnya sanksi hingga tidak menimbulkan efek jera bagi para pelanggar.

Hukum dan sanksi dapat diibaratkan sebuah mata uang logam, dimana sisi yang satu merupakan bagian dari sisi yang lain bila suatu norma hukum tidak memiliki sanksi maka normanya dikategorikan sebagai norma moral. Dalam Hukum, sanksi sangat penting untuk mengefektifitaskan suatu peraturan, karena sanksi dianggap sebagai suatu cara yang sampai sekarang masih dianggap efektif untuk memberikan efek jera bagi pelanggar hukum. Oleh karena hal tersebut penulis terdorong untuk melakukan penelitian yang mendalam mengenai efektifitas penerapan Pasal 33 ayat (2) Undangundang No 7 Tahun 2011 Tentang mata uang.

Oleh karena kompleksitas dan keterkaitan masalah hukum yang dibahas di atas maka identifikasi masalah yang akan dibahasa adalah Bagaimana penerapan Pasal 33 ayat (2) Undang-undang Nomor 7 Tahun 2011 tentang Mata Uang di Maluku.

\section{METODE PENELITIAN}

Jenis penelitian yang digunakan dalam penulisan ini adalah Yuridis Empiris, Metode Pendekatan yang digunakan dalam penelitian ini adalah metode yuridis empiris. 
Penelitian yuridis empiris adalah penelitian hukum mengenai pemberlakuan atau implementasi ketentuan hukum normatif secara in action pada setiap peristiwa hukum tertentu yang terjadi dalam masyarakat. ${ }^{4}$

Penulisan ini bersifat deskriptif analitis, dimana dengan menggunakan pendekatan di atas dapat didiskripsikan berbagai temuan yang akan dianalisis dan dibahas dalam suatu sistem penelitian sehingga dengan hasil deskripsi tersebut dapat ditarik suatu kesimpulan dan dilengkapi dengan saran-saran. ${ }^{5}$

\section{ANALISIS}

\section{Mata uang sebagai legal tender (penawaran/pembayaran yang sah)}

Dalam lalu lintas perekonomian baik nasional maupun internasional, lazimnya uang diartikan sebagai alat pembayaran yang sah. Pada kehidupan manusia sehari-hari, uang merupakan bagian integral yang tidak dapat dipisahkan dari kehidupan itu sendiri. Uang adalah sesuatu yang secara umum diterima di dalam pembayaran untuk pembelian barang-barang dan jasa-jasa serta untuk pembayaran hutang-hutang. Uang juga sering dipandang sebagai kekayaan yang dimilikinya yang dapat digunakan untuk membayar sejumlah tertentu hutang dengan kepastian dan tanpa penundaan. Lazimnya uang memiliki karakteristik, akseptabilitas dan kognitif, stabilitas nilai, elastisitas pasokan, portabilitas, daya tahan, keterbacaan. Sebagai sarana perekonomian, uang memiliki empat fungsi, yaitu: alat pertukaran, unit penghitung, penyimpanan nilai dan standar untuk pembayaran tertangguhkan. Uraian di atas menunjukkan betapa pentingnya uang di dalam lalu lintas perekonomian dan pergaulan masyarakat suatu negara. Oleh karena itu di Indonesia tentang uang ini di atur dalam konstitusi yaitu Pasal 23B Undangundang Dasar 1945, yang menentukan bahwa : "Macam dan harga mata uang ditetapkan dengan Undang-Undang”.

Pengaturan lebih lanjut tentang uang ini dimuat di dalam Pasal 2 Undang-Undang No. 23 Tahun 1999 tentang Bank Indonesia, sebagaimana telah diubah dengan UndangUndang No. 3 Tahun 2004, bahwa : "Satuan mata uang negara Republik Indonesia adalah rupiah (Rp.)".

Uang rupiah adalah alat pembayaran yang sah di wilayah negara Republik Indonesia. Dalam fungsinya sebagai alat pembayaran yang sah, maka setiap perbuatan yang menggunakan uang atau mempunyai tujuan pembayaran atau kewajiban yang harus dipenuhi dengan uang jika dilakukan di wilayah negara Republik Indonesia wajib menggunakan uang rupiah, kecuali ditetapkan secara lain. Demikian juga setiap orang atau badan yang berada di wilayah negara Republik Indonesia dilarang menolak untuk menerima uang rupiah yang penyerahannya dimaksudkan sebagai pembayaran atau memenuhi kewajiban yang harus dipenuhi dengan uang.

Penggunaan Rupiah Sebagai Legal Tender, "Legal tender is a payment that can not be refused in settlement of debt"( Legal tender adalah pembayaran yang tidak dapat ditolak dalam penyelesaian hutang). Legal tender pada prinsipnya adalah sebuah ketentuan hukum yang menyatakan bahwa suatu alat pembayaran dapat diterima secara umum sebagai alat pembayaran yang sah secara hukum dan tidak dapat ditolak sebagai

\footnotetext{
${ }^{4}$ Abdulkadir Muhammad, “Hukum dan Penelitian Hukum”, Citra Aditya Bakti, Bandung, 2004, hal 134

${ }^{5}$ Soejono Soekanto, Pengantar Penelitian Hukum, UI Press, Jakarta,1986, hal 10
} 
alat pembayaran. Definisi tersebut dalam prakteknya kemudian mengalami perkembangan, khususnya mengenai:

1. Batasan apa saja yang tergolong dalam legal tender, apakah hanya terbatas pada uang kartal baik uang kertas maupun uang koin ataukah juga menjangkau pada alat pembayaran yang lain seperti cek, kartu kredit, dan kartu debit serta berbagai alat pembayaran sejenis dengan metode bukan mata uang.

2. Keharusan penggunaan legal tender tersebut apakah mencakup semua transaksi pembayaran atau pemenuhan kewajiban seperti yang tercantum dalam Nepal Renstra Bank Act "Tanda mata uang yang dikeluarkan oleh bank ini adalah pelelangan yang sah atas pembayaran jumlah yang diekspresikan di seluruh kerajaan Nepal" ataukah hanya berupa pembayaran transaksi hutang piutang.

Praktik yang terjadi di dunia, bahwa sampai dimanakah batasan legal tender kemudian menjadi kewenangan sepenuhnya dari negara masing-masing untuk menentukan, yang kemudian dituangkan baik dalam Undang-Undang Mata Uang (currency act) maupun dalam Undang-Undang Bank Central (Central Bank Act), sehingga batasan legal tender antara negara yang satu dengan negara lain akan berbeda-beda. Di Amerika Serikat, definisi legal tender berdasarkan Coinage Act of 1965, khususnya bagian 31 menyatakan "Legal tender, "yang menyatakan:" koin dan mata uang Amerika Serikat (termasuk catatan cadangan federal dan catatan sirkulasi bank cadangan dan bank nasional Federal) adalah pelelangan sah untuk semua hutang, retribusi publik, pajak, dan iuran. "Sehubungan dengan transaksi pribadi, ini telah ditafsirkan hanya berlaku untuk "pembayaran hutang bila diajukan ke kreditur." Berdasarkan definisi tersebut berarti pengertian legal tender di U.S adalah tidak hanya sebatas uang kartal saja tetapi juga penggunaan uang modern seperti kartu kredit. Dunia usaha, masyarakat, dan organisasi bebas menetukan dengan model apa mereka akan melakukan pembayaran, bahkan beberapa toko di Amerika Serikat telah mengambil kebijakan untuk menolak pembayaran dengan denominasi besar (biasanya di atas USD 20), baik untuk keseluruhan transaksi maupun untuk transaksi tertentu saja. Hal ini dimaksudkan agar mereka tetap memiliki pecahan mata uang yang cukup seimbang pada kasirnya dan juga sebagai pengaman jika pada suatu ketika terjadi perampokan. Demikian pula dalam hal penggunaan legal tender di Amerika tidak hanya sebatas untuk pembayaran hutang tetapi juga untuk pungutan publik, pajak dan retribusi.

Sementara di Indonesia batasan tentang legal tender diatur dalam Undang-Undang No. 23 Tahun 1999 tentang Bank Indonesia sebagaimana telah diubah dengan UndangUndang No. 3 Tahun 2004. Pengaturan tersebut terdapat dalam Pasal 2 Undang-Undang No 3 Tahun 2004 yang berbunyi sebagai berikut: (1) Satuan mata uang negara Republik Indonesia adalah Rupiah yang di singkat dengan Rp. (2) Uang Rupiah adalah alat pembayaran yang sah di wilayah negara Republik Indonesia. (3) Setiap Perbuatan yang menggunakan uang atau mempunyai tujuan pembayaran atau kewajiban yang harus dipenuhi dengan uang jika dilakukan di wilayah Republik Indonesia wajib menggunakan uang rupiah, kecuali apabila ditetapkan lain dengan peraturan Bank Indonesia. (4) Setiap orang atau badan yang berada di wilayah Negara Republik Indonesia dilarang menolak untuk menerima uang rupiah yang penyerahannya dimaksudkan sebagai pembayaran atau pemenuhan kewajiban yang harus dipenuhi dengan uang sebagaimana dalam ayat (3). (5) Pengecualian sebagaimana dimaksud dalam ayat (3) diberikan untuk keperluan pembayaran di tempat atau di daerah tertentu, untuk maksud pembayaran, atau untuk memenuhi kewajiban dengan valuta asing yang 
telah diperjanjikan secara tertulis, yang akan ditetapkan dengan peraturan Bank Indonesia.

Berdasarkan ketentuan tersebut maka untuk kategori legal tender tidak ada pembatasan wujud uang rupiah, berarti tidak ada keharusan bahwa yang merupakan alat pembayaran yang sah adalah uang kartal baik uang kertas maupun uang koin sebagaimana yang berlaku pada beberapa negara lain. Ketentuan Pasal 2 tersebut pada prinsipnya melahirkan 2 ketentuan yang harus dipenuhi oleh setiap orang dan badan yang berada dalam wilayah Republik Indonesia yaitu: wajib menggunakan mata uang rupiah sebagai alat pembayaran; dan dilarang menolak pembayaran dengan rupiah bagi penerima pembayaran. Aturan ini mengharuskan kepada setiap orang atau badan apapun kewarganegaraannya, dengan apapun model dan jenis transaksinya selama berada di wilayah Republik Indonesia dan menggunakan alat pembayaran maka harus merujuk pada rupiah dan tidak diperbolehkan untuk menggunakan mata uang lain. Pemuatan aturan ini dalam Undang-Undang berarti bahwa aturan tersebut adalah suatu kewajiban yang harus dilakukan dan sesuai dengan azas hukum yang menyatakan bahwa ketika suatu Undang-Undang diundangkan berarti semua orang dianggap tahu, maka semua orang atau badan yang berkaitan dengan aturan tersebut dianggap dan dibebani kewajiban untuk melaksanakan. Keharusan penggunaan mata uang Rupiah dalam wilayah Negara Kesatuan Republik Indonesia ini mengingat mata uang merupakan salah satu simbol kedaulatan negara, yang harus ditegakkan keberadaannya. Penggunaan mata uang rupiah di wilayah Republik Indonesia berarti penghormatan terhadap kedaulatan Indonesia, sementara penggunaan mata uang asing di wilayah Republik Indonesia dengan mengesampingkan mata uang rupiah berarti merupakan salah satu tindakan penjajahan terhadap kedaulatan Bangsa Indonesia khususnya di bidang ekonomi yang berpotensi besar untuk menyerang bidang-bidang lain di wilayah Republik Indonesia.

Prinsip dalam pembuatan suatu peraturan selain dimaksudkan untuk mengatur juga diusahakan mampu dilaksanakan, yang berarti dalam pelaksanaannya tidak boleh terlalu membebani atau membatasi. Demikian pula dalam keharusan penggunaan rupiah, aturan ini pada prinsipnya adalah untuk meningkatkan nilai rupiah. Menyadari bahwa saat ini rupiah bukanlah merupakan hard money dan belum pula semua negara mau menerima uang rupiah, maka pengaturan pengecualian terdapat penggunaan rupiah tetap diperlukan. Hal ini dimaksudkan agar jangan sampai pembebanan keharusan penggunaan rupiah ini justru membatasi kegiatan perekonomian yang nantinya berpotensi membawa keterpurukan ekonomi bangsa Indonesia. Prinsip pengecualian ini juga dianut beberapa negara lain seperti Kanada. Saat ini tidak semua transaksi di wilayah Republik Indonesia bisa menggunakan rupiah, tetapi seharusnya pengecualiannya adalah dengan pembatasan yang tegas, sehingga tidak mengaburkan kewajiban pengunaan rupiah sebagai legal tender. Pembatasan yang tegas tersebut dapat dilakukan misalnya dengan mengatur pengecualian penggunaan rupiah tersebut dalam sebuah Peraturan Pemerintah yang dikeluarkan oleh presiden sehingga lebih menjamin implementasi pengaturan kewajiban penggunaan uang rupiah. ${ }^{6}$

${ }^{6}$ Tim Peneliti Fakultas Hukum UGM, Pengaturan Mata Uang Republik Indonesia, Buletin Hukum Perbankan dan Kebanksentralan, Volume 4 Nomor 1, April 2006, hal. 29-34 


\section{Pengaturan Mata Uang menurut perundang-undang di Indonesia}

Untuk memenuhi kebutuhan akan uang, pemerintah Negara yang bersangkutan melalui bank sentral berhak menciptakan uang, terutama uang kartal. Begitu pula dengan jumlah uang yang beredar perlu dijaga agar nilai uang tetap tetap stabil. Kemudian kebutuhan akan uang giral biasanya di cetak oleh bank-bank umum dimana jumlahnya jauh melebihi jumlah uang kartal yang beredar. Dalam hal berkaitan dengan uang maka peranan lembaga keuangan terutama bank sangatlah besar, hal ini sesuai dengan fungsi lembaga keuangan yaitu sebagai perantara keuangan di masyarakat.

Oleh karena itu di banyak negara, pengaturan tentang mata uang ini dimuat di dalam konstitusi (Undang-Undang Dasar) dari negara yang bersangkutan. Di Indonesia, ketentuan tentang mata uang ini dimuat di dalam Pasal 23 ayat (3) Undang-Undang Dasar Negara Republik Indonesia Tahun 1945 (UUD 1945 sebelum amandemen) yang menentukan bahwa: "Macam dan harga mata uang ditetapkan dengan Undang-Undang". Ketentuan yang sama diatur kembali dalam Pasal 23B UUD 1945 setelah amandemen keempat. Pengaturan lebih lanjut tentang mata uang ke dalam Undang-Undang organik dimuat dalam Undang-Undang No. 23 Tahun 1999 tentang Bank Indonesia, sebagaimana telah diubah dengan Undang-Undang No. 3 Tahun 2004 (selanjutnya disingkat UU Bank Indonesia). Di dalam UU Bank Indonesia tersebut ketentuan secara materiil tentang mata uang diatur dalam Pasal 2, Pasal 19, Pasal 20, Pasal 21, Pasal 22 , Pasal 23, dan Pasal 77A. Selanjutnya ketentuan formal khususnya yang menyangkut sanksi diatur dalam Pasal 65, Pasal 66, dan Pasal 72. Di samping itu ketentuan tentang sanksi pidana juga masih mendasarkan pada Bab X Buku Kedua tentang Kejahatan Kitab Undang-Undang Hukum Pidana (KUHP). Meskipun secara materiil pengaturan tentang macam dan harga mata uang di dalam UU Bank Indonesia dan KUHP dirasakan telah mencukupi, akan tetapi dalam perkembangannya pengaturan yang demikian itu dianggap kurang pas dan tidak sesuai dengan semangat UUD 1945 yang mengamanatkan pengaturannya dengan Undang-Undang tersendiri yang secara khusus mengatur materi tersebut. Ada alasan-alasan yang dapat digunakan sebagai dasar agar pengaturan mata uang dituangkan dalam Undang-Undang tersendiri, sebagaimana diuraikan berikut ini. Pasal 23B UUD 1945 Amandemen keempat menentukan bahwa "macam dan harga mata uang ditetapkan dengan Undang-Undang". Kata "dengan" mengandung makna bahwa pengaturan lebih lanjut dilakukan dengan menuangkan dalam Undang-Undang yang khusus mengatur tentang itu.

Kata "dengan" tersebut berbeda dengan kata "dalam" Undang-Undang, yang mempunyai makna bahwa pengaturan lebih lanjut dapat dimasukkan dalam UndangUndang apa saja yang terkait dengan materi yang bersangkutan, dengan demikian dapatlah ditafsirkan bahwa pengaturan lebih lanjut dari macam dan harga mata uang dituangkan dalam bentuk Undang-Undang tersendiri. Di dalam UUD 1945 setelah Amandemen keempat, pengaturan macam dan harga mata uang dipisah dalam pasal yang berbeda dengan pengaturan bank sentral. Sebagaimana telah disebutkan di muka bahwa pengaturan macam dan harga mata uang diatur dalam Pasal 23B, sementara itu tentang bank sentral diatur dalam Pasal 23D yang menentukan bahwa "Negara memiliki suatu bank sentral yang susunan, kedudukan, kewenangan, tanggung jawab, dan independensinya diatur dengan Undang-Undang". Pemisahan pengaturan tersebut dapat saja ditafsirkan bahwa pengamandemen batang tubuh UUD 1945 menghendaki agar kedua materi tersebut diatur secara terpisah dalam Undang-Undang yang berbeda. Pasal 77A UU Bank Indonesia menentukan bahwa "Ketentuan mengenai mata uang 
sebagaimana dimaksud dalam Pasal 2, Pasal 19, Pasal 20, Pasal 21, Pasal 22, dan Pasal 23 Undang-Undang ini dinyatakan tetap berlaku hingga diatur lebih lanjut dengan Undang-Undang tersendiri”. Ketentuan Pasal 77A tersebut tersirat makna bahwa tentang mata uang akan diatur dengan Undang-Undang tersendiri terlepas dari UU Bank Indonesia. Era reformasi dewasa ini memungkinkan timbulnya perubahan-perubahan yang kadang-kadang terjadi secara tiba-tiba dan tidak terencana sebelumnya, baik di bidang politik, pemerintahan maupun perekonomian.

Perubahan tersebut tentunya akan berimbas terhadap kebijakan yang akan diterapkan oleh lembaga/pejabat baru hasil perubahan. Oleh karena itu, pengaturan secara mandiri terhadap berbagai substansi dalam UndangUndang tersendiri menjadi sangat penting. Sehingga apabila terjadi perubahan pengaturan dan kebijakan kewenangan terhadap substansi tertentu tidak akan begitu mempengaruhi pada substansi terkait lainnya. Meskipun demikian perlu diingat bahwa hukum merupakan suatu sistem, artinya bahwa hukum itu merupakan suatu kesatuan tatanan yang utuh yang terdiri dari bagianbagian atau unsur-unsur yang saling berkaitan erat satu sama lain. Jadi meskipun pengaturannya dipisahkan, tetapi sebenarnya tetap merupakan satu kesatuan tatanan yang saling berkaitan antara aturan yang satu dengan lainnya. Disamping alasan-alasan tersebut di atas, secara historis di Indonesia pernah diberlakukan Undang-Undang yang khusus mengatur tentang mata uang, yaitu:

1. Undang-Undang Darurat Nomor 20 Tahun 1951 Tentang Penghentian Berlakunya "Indische Muntwet 1912" dan Penetapan Peraturan Baru tentang Mata Uang;

2. Undang-Undang Nomor 27 Tahun 1953 Tentang Penetapan "UndangUndang Darurat Tentang Penghentian Berlakunya "Indische Muntwet 1912" dan Penetapan Peraturan Baru tentang Mata Uang (Undang-Undang Darurat Nomor 20 Tahun 1951) Sebagai Undang-Undang;

3. Undang-Undang Darurat Nomor 4 Tahun 1958 tentang Pengubahan "UndangUndang Mata Uang Tahun 1953"; dan

4. UndangUndang Nomor 71 Tahun 1958 Tentang Penetapan "Undang-Undang Darurat Nomor 4 Tahun 1958 Tentang Pengubahan Undang-Undang Mata Uang Tahun 1953" Sebagai Undang-Undang.

Berdasarkan alasan-alasan tersebut di atas, baik alasan dari segi normatif, sosiologis, historis, maka perlu kiranya untuk dipikirkan kemungkinan pengaturan macam dan harga mata uang terpisah dari pengaturan tentang Bank Indonesia. Dengan pengaturan dalam Undang-Undang yang terpisah, maka sangat dimungkinkan pengaturan macam dan harga mata uang akan lebih komprehensif serta lebih banyak mengatur normanorma yang selama ini dituangkan dalam Peraturan Bank Indonesia. Sementara itu dengan ditingkatkannya norma-norma dalam Peraturan Bank Indonesia ke dalam Undang-Undang, maka untuk selanjutnya Peraturan Bank Indonesia lebih difokuskan pada ketentuan-ketentuan yang bersifat teknis operasional maupun administratif. Suatu peraturan yang baik harus memiliki landasan peraturan perundang-undangan, yaitu landasan filosofis, landasan sosiologis, dan landasan yuridis. Landasan filosofis (filosofische grondslag) menentukan bahwa suatu rumusan peraturan perundangundangan harus mendapatkan pembenaran yang dapat diterima jika dikaji secara filosofis. Landasan sosiologis (sociologische grondslag) menentukan bahwa suatu peraturan perundang-undangan harus sesuai dengan keyakinan umum atau kesadaran hukum masyarakat. Landasan yuridis (rechtgrond) menentukan bahwa suatu peraturan 
perundang-undangan harus mempunyai landasan hukum atau dasar hukum atau legalitas yang terdapat dalam ketentuan lain yang lebih tinggi.

Dalam peraturan mata uang juga diharapkan memiliki ketiga landasan tersebut, sehingga nantinya dapat dikualifikasikan sebagai peraturan yang baik. Selanjutnya mengenai materi muatan dari pengaturan mata uang, di dalam Pasal 1 butir 12 UU Pembentukan Peraturan Perundang-undangan ditentukan bahwa "materi muatan peraturan perundang-undangan adalah materi yang dimuat dalam peraturan perundangundangan sesuai dengan jenis, fungsi, dan hierarki peraturan perundang-undangan”. Materi muatan yang akan dituangkan dalam peraturan mata uang paling tidak harus mampu menampung materi-materi yang selama ini sudah diatur baik di dalam UU Bank Indonesia, KUHP, maupun yang diatur dalam Peraturan Bank Indonesia yang bersifat mengatur, setelah diadakan penyesuaian dengan perkembangan dewasa ini. Disamping itu peraturan mata uang ini harus mampu menambah materi muatan baru yang selama ini belum diatur di dalam beberapa peraturan yang telah disebut tadi. Dengan demikian peraturan mata uang yang baru mampu memberikan pencerahan baik dari segi kepastian, kelancaran operasional maupun efektivitas dan efisiensi kerja serta pertumbuhan perekonomian secara nasional. Dengan mengkombinasi materi yang sudah diatur dalam berbagai aturan tersebut dengan penyesuaian-penyesuaian secukupnya dan penambahan materi baru yang dianggap perlu, maka pokok-pokok materi muatan yang seyogianya dimuat dalam peraturan mata uang adalah sebagai berikut:

1. Macam, Satuan dan harga mata uang negara Republik Indonesia;

2. Uang rupiah sebagai alat pembayaran yang sah (legal tender);

3. Kewenangan Bank Indonesia sebagai bank sentral;

4. Penukaran Uang;

5. Pengawasan pelaksanaan kewenangan Bank Indonesia;

6. Ketentuan Pidana;

7. Ketentuan Peralihan;

8. Ketentuan Penutup.

\section{Peredaran Uang sebagai alat transaksi di Maluku}

Dalam masyarakat ekonomi modern sekarang ini uang merupakan bagian Intergral dari kehidupan dan darah perekonomian. Di mana lalu lintas barang dan jasa serta semua kegiatan ekonomi menggunakan uang sebagai alatnya, tidak ada satupun perdaban di dunia ini yang tidak mengenal dan menggunakan uang. Kalaupun ada maka perekonomian pada peradaban tersebut akan stagnan dan tidak berkembang. Uang adalah persediaan aset yang dapat dengan segera di gunakan untuk melakukan transaksi. Semakin banyak seseorang memiliki uang maka dianggap semakin kaya. Peran uang dalam perkonomian dapat diibaratkan darah yang mengalir dalam tubuh manusia. Ketika manusia kekurangan uang, bagaikan manusia yang kekurangan darah, sehingga mengakibatkan gairah hidup manusia menurun dan melemah. Dinamika perekonomian dan perputaran uang hanyalah salah satu sisi dari Interaksi manusia, dan karenanya ia mencerminkan karakter dan sifat manusia itu sendiri yang bertindak atas dasar harapan dan kecemasannya, rasionalitas maupun irasionalitasnya terhadap uang.

Bank Indonesia senantiasa berupaya untuk dapat memenuhi kebutuhan uang kartal di masyarakat baik dalam nominal yang cukup, jenis pecahan yang sesuai, tepat waktu dan kondisi yang layak edar. Uang yang dikenal saat ini telah mengalami proses

\footnotetext{
${ }^{7}$ Tim Peneliti Fakultas Hukum UGM, Op, Cit, hal. 38-42
} 
perkembangan yang panjang, keberadaan uang menyediakan alternatif yang lebih mudah serta lebih efisien dalam sebuah transaksi dari pada barter yang lebih kompleks, tidak efisien, dan kurang cocok digunakan dalam sistem ekonomi modern karena dalam transaksinya membutuhkan orang yang memiliki keinginan yang sama untuk melakukan pertukaran dan akan kesulitan dalam penentuan nilai. Efeisiensi yang didapatkan dengan menggukan uang pada akhrinya akan mendorong perdagangan. Uang memiliki 3 (tiga) fungsi yaitu : sebagai media pertukaran (medium of exchange). Sebagai penyimpan nilai (store of value), sebagai satuan hitung (unif of account). Uang kartal yang di keluarkan oleh Bank Indonesia menurut Undang-undang No. 13 Tahun 1986 tentang Bank Sentral Pasal 26 ayat 1, memiliki dua jenis yaitu : Uang logam dan Uang kertas. Perputaran uang kartal tidak terlepas dari pertumbuhan ekonomi, sebagaimana Inflasi dan pertumbuhan ekonomi bagaikan dua sisi mata uang. Kedua hal itu terkait erat. Di satu sisi, pertumbuhan ekonomi yang positif akan meningkatkan kesejahteraan masyarakat sehingga akan memicu terjadinya inflasi. Dengan kata lain inflasi akan terkompensasi oleh tingkat pertumbuhan ekonomi yang cukup tinggi. Karakteristik inflasi suatu daerah sendiri sangat tergantung dari struktur perekonomian daerah tersebut. Oleh karenanya, program dan langkah-langkah yang bisa diaplikasikan dalam mendorong pertumbuhan ekonomi yang bisa mengkompensasikan laju inflasi bersifat sangat spesifik antar daerah.

Hal ini diakibatkan oleh bebeapa faktor yang menyebabkan terjadinya inflasi di Maluku adalah tingginya tingkat konsumsi di Maluku dan juga didorong oleh tingginya level harga barang dan jasa sehinga hal ini berdampak terhadap tingginya kebutuhan masyarakat dan mempengaruhi daya beli masyarakat yang lemah, sehingga kebutuhan akan uang kartal memang perlu.

Meningkatnya peredaran uang kartal pada triwulan IV 2016 di Maluku tetapi tidak di Kabupaten se Maluku seluruhnya tidak semua peredaran uang kartal berfungsi sebagai alat transaksi khususnya uang logam, baik itu bagi masyarakat atau para pedagang. Padahal uang kartal (uang kertas dan uang logam) yang dikeluarkan oleh Bank Indonesia merupakan alat transaksi yang sah. Hal ini di sebabkan oleh beberapa faktor : Pertama, masyarakat tidak menggunakan uang kartal (logam) karena para pedagang tidak menerima atau memakai uang logam sebagai media transaksi. Ke Dua, tingginya harga kebutuhan pokok sehingga tidak ada kebutuhan pokok masyarakat yang di perdagangkan dalam bentuk pecahan logam. Ke Tiga, minimnya pengetahuan masyarakat terhadap uang kartal (logam) yang pada esensinya bisa ditukarkan pada pihak yang bertanggungjawab (Bank) yang merupakan lembaga intermediasi. Hal ini memicu meningkatnya harga kebutuhan pokok (inflasi) yang di sebabkan tidak berfungsinya uang (logam). Ketika terjadi inflasi maka akan mendorong kebutuhan masyarakat akan uang kartal, tetapi yang dibutuhkan hanya uang kertas bukan uang logam karena masyarakat Maluku tidak menganggap uang logam sebagai instrument yang berguna sebagai alat pertukaran, hal ini merupakan sebuah masalah yang akan memicu inflasi dan menghambat perekonomian Maluku. Padahal Bank merupakan lembaga intermediasi.

Dimana menurut Pasal 1 Ayat (2) Undang-undang Perbankan No. 10 Tahun 1998 menjelaskan bahwa :

Bank merupakan badan usaha yang menhimpun dana dari masyarakat yang kelebihan dana kemudian di salurkan kepada masyarakatyang membutuhkan dana dalam rangka meningkatkan taraf hidup masyarakat. 
Bank Indonesia maupun Bank Umum selalu mengedarkan uang logam, namun masyarakat tidak menggunakan uang logam sebagai alat transaksi, dan berdampak pada harga bahan kebutuhan pokok di Maluku yang di perdagangkan tidak dalam bentuk pecahan logam. Sehingga uang logam yang beredar di Maluku hanya tertahan di tangan masyarakat maupun di kalangan para pedagang. Di karenakan ketika konsumen bertransaksi dengan menggunakan uang logam untuk memenuhi kebutuhan pokoknya, maka para pedagang eceran tidak menerima jika menggunakan uang logam: "Saya akan kesulitan untuk membeli pasokan barang dalam jumlah yang kecil maupun yang besar jika menggunakan uang logam karena pedagang yang lain tidak mau menerima uang logam".

\section{Kendala-Kendala yang Dihadapi Dalam Penerapan Pasal 33 ayat (2) Undang-Undang Nomor 7 Tahun 2011 Tentang Matau Uang di Maluku}

Dalam menjalankan tugasnya pemerintah khusnya instansi yang terkait bank Indonesia dan kepolisian memiliki sejumlah hambatan yang dimiliki untuk mencegah terjadinya praktek penolakan pembayaran dengan mata uang rupiah, adapun hambatan yang dihadapi adalah sebagai berikut:

1. Kurangnya sosialisasi kepada masyarakat terkait hukum oleh instansi terkait, sehingga masyarakat beralasan bahwa ada aturan yang melarang menolak pembayaran dengan rupiah. Hal ini sangat bertentangan dengan teori fiksi hukum, bahwa begitu suatu norma hukum diberlakukan, maka saat itu pula setiap orng dianggap tahu hukum. Ketidaktahuan seseorang akang hukum tidak dapat membebaskan orang itu dari tuntutan hukum.

2. Rendahnya kesadaran hukum yang dimiliki oleh masyarakat itu sendiri, untuk itu diperlukan deperlukan peningkatan penyuluhan hukum untuk memeratakan kesadaran hukum masyarakat.

3. Tidak adanya pelaporan dari masyarakan kepada pihak kepolisian akan pelanggaran itu tersebut, sehinga praktik pelanggaran tersebut semakin marak dilakukan, hal ini sesuai dengan hasil wawancara dengan Bapak Richard S Tupamahu, Jabatan Ba Sat Reskrim, Kesatuan Polres Pulau Ambon dan Pulaupulau Lease pada hari Senin 16 Oktober 2017, Pukul 13:30 WIT, Di Kantor Sat Reskrim Polres Pulau Ambon dan Pulau-pulau Lease. ${ }^{9}$ Menurut beliau bentuk dari delik ini adalah delik aduan dengan unsur :
a. Setiap orang
b. dilarang menolak untuk menerima Rupiah
c. yang penyerahannya dimaksudkan sebagai pembayaran atau untuk menyelesaikan kewajiban yang harus dipenuhi dengan Rupiah dan/atau untuk transaksi keuangan lainnya.
d. Wilayah Negara Kesatuan Republik Indonesia.
e. kecuali karena terdapat keraguan atas keaslian Rupiah.

Dari kelima unsur diatas diketahui bahwa Rupiah adalah Legal Tender, alat pembayaran yang sah, jika ada penolakan seseorang dengan mengunakan rupiah karena berbentuk uang gobang maka seharusnya dia dipidana, karena menolak transaksi dengan Rupiah di Wilayah Indonesia, dan harus ada laporan bahwa telah terjadi penolakan, tanpa ada hal

\footnotetext{
${ }^{8}$ Hasil Wawancara Dengan, Daeng Sain. Salah seorang pedagang Di Maluku Tenggah, Desa Morella, Kecamatan Leihitu, 28 September 2017, pukul 10:30 WIT.

${ }^{9}$ Hasil Wawancara dengan Bapak Richard S Tupamahu.SH, Jabatan Ba Sat Reskrim, Kesatuan Polres Pulau Ambon dan Pulau-pulau Lease pada hari Senin 16 Oktober 2017, Pukul 13:30 WIT
} 
tersebut maka tidak dapat dilakukan penyidikan dan penyelidikan. Oleh karena itu, dibutuhkan kerja sama yang baik antara instansi pemerintah yang terkait dengan pihak kepolisian agar aktif memberikan pengetahuan akan aturan-aturan yang ada didalam perundang undangan, agar aturan-aturan itu diketahui dan dijalankan oleh semua masyarakat khususnya di Maluku.

Untuk mencegah praktek penolakan pembayaran dengan mata uang rupiah, dalam ilmu hukum pidana dikenal ada dua cara atau usaha untuk menanggulangi kejahatan atau pelanggaran yaitu upaya preventif (mencegah sebelum terjadinya kejahatan) dan upaya represif (usaha sesuda terjadinya kejahatan).

1. Bentuk upaya preventif

Berdasarkan hasil wawancara dengan Bapak Hujianto Pegawai Bank Indonesia Kantor Perwakilan Maluku Staf Bagian Unit Pengawasan Sistem Pembayaran, Pengelolaan Uang Rupiah dan Keuangan inklusif (unit pengawasan sp, pur dan ki) menyatakan bahwa telah banyak melakukan upaya pencegahan sebagai bentuk upaya penanggulangan terhadap penolakan pembayaran dengan mata uang rupiah dalam transasksi pembayaran, antara lain:

1) Sosialisasi

Dalam hal ini bank Indonesia telah melakukan sosialisasi terkait dengan mata uang, baik dari bagaimana penggunaan uang dengan baik, sampai dengan masalah berlakunya mata uang rupiah termasuk uang logam pecahan Rp.50, Rp,100, Rp,200. Sosialisasi dilakukan disejumlah Sekolah sekolah, dan perguruan tinggi di Maluku khususnya kota Ambon.

2) Media masa

Dalam hal ini bank Indonesia telah melakukan himbauan melalui media massa surat kabar, yang antara lain menyebutkan larangan menolak pembayaran dengan mata uang rupiah yang masih berlaku dan bagi yang melakukan akan dipidana sesuai ketentuan perundang undangan yang berlaku.

Bank Indonesia sampai detik ini selalu menghimbau masyarakat untuk tetap menggunakan nominal tersebut dengan penegasan bahwa uang logam tersebut masih berlaku decara sah di Indonesia.

\section{Bentuk upaya represif}

Usaha tersebut bertujuan untuk mengurangi kerugian yang terjadi, dengan kata lain bahwa pelaku yang telah melakukan pelanggaran tersebut telah diberikan hukuman oleh penegak hukum. Upaya ini dilakukan pada saat telah terjadi tindak pidana yang tindakannya berupa penegakan hukum dengan menjatuhkan hukuman.

Upaya represif yang dilakukan Bank Indonesia antara lain adalah sebagai berikut :

1) Melakukan sidak

Bank Indonesia dalam hal ini pernah melakukan sidak atau turun langsung ke lapangan, baik ke pasar-pasar tradisional maupun ke pertokoan. Hal ini di lakukan untuk memberi tahu langsung dan nasehat kepada masyarakat khususnya pedagang agar tidak melakukan praktek penolakan mata uang rupiah.

2) Surat teguran

Bank Indonesia dalam hal ini pernah memberikan surat teguran terhadap salah satu pusat perbelanjaan besar di Maluku yang melakukan praktek penelokan 
mata uang rupiah, surat teguran diberikan agar memberikan peringatan kepada pelakau agar tidak lagi melakukan hal tersebut.

Bank Indonesia sejauh ini belum pernah melaporkan setiap pelaku kepada penegak hukum, yaitu kepolisian. Bank Indonesia beralasan bahwa hampir seluruh masyarakat khususnya pedagang melakukan praktek tersebut, sehingga tidak mungkin semua masyarakat khususnya pedagang di Maluku di laporkan dan diproses pidana. Sedangkan upaya represif dari penegak hukum, yaitu kepolisian Maluku tidak pernah menindak pelaku penolakan pembayaran dengan mata uang rupiah di sebabkan karena tidak adanya pelaporan dari masyarakat di Maluku, perbuatan tersebut baru dapat diproses oleh kepolisian kalau adanya aduan, karena perbuatan pelanggaran tersebut merupakan delik aduan.

\section{SIMPULAN}

Penerapan sanksi pidana terhadap penolakan pembayaran dan mata uang rupiah khususnya di Kota Ambon tidak berjalan dengan semestinya. Terbukti dengan data dari polres pulau ambon dan pulau-pulau lease yang menyatakan bahwa tidak adanya penerapan sanksi pidana terhadap pelanggaran tersebut, karena tidak adanya pelaporan sehingga tidak dapat diproses. Adapun upaya penangulangan yang telah dilakukan dalam usaha pencegahan penolakan pembayaran dengan mata uang rupiah yaitu, secara preventif (upaya pencegahan sebelum terjadinya tindak pidana) dari Bank Indonesia, sampai detik ini adalah selalu menhimbau masyarakat untuk tetap mengguanakan nominal pecahan kecil tersebut dengan menegaskan bahwa uang logam tersebut masih berlaku secara sah di Indonesia. Upaya lainnya adalah dengan melakukan sosialisasi terhadap masalah ini dan memberitahukan melakukan melalui media masa, seperti Koran, yang mengatakan menolak pembayaran dengan mata uang rupiah bisa di penjara. Secara represif (upaya yang dilakukan setelah terjadinya tindak pidana), yaitu dari bank Indonesia adalah berupa teguran langsung dan memberikan nasihat semata bahwa perbuatan penolakan pembayaran dengan mata uang rupiah itu dapat dikenakan sanksi pidana menurut Undang-undan Nomor 7 Tahun 2011 Tentang Mata Uang. Sedangkan upaya represif dari penegak hukum, yaitu kepolisan Maluku tidak pernah menindak pelaku penolakan pembayaran dengan mata uang rupiah disebabkan karena tidak adanya pelaporan dari masyarakat di Maluku, perbuatan tersebut baru dapat diproses oleh kepolisian setelah adanya aduan, karena perbuatan pelanggaran tersebut merupakan delik aduan. Adapun kendala yang di hadapi adalah rendahnya kesadaran hukum yang dimiliki oleh masyarakat itu sendiri, faktor lingkungan dengan mengikuti perbuatan yang dilakukan oleh orang lain serta tidak adanya pelaporan dari masyarakat akan pelanggaran tersebut.

\section{DAFTAR PUSTAKA}

\section{Buku dan Jurnal}

Abdulkadir Muhammad, Hukum dan Penelitian Hukum, Citra Aditya Bakti, Bandung, 2004.

Agus Pamungkas Amandemen UUD 1945.

Edi Setiadi Dan Rena Yulia, Hukum Pidana Ekonomi, Edisi Pertama, Cetakan Pertama, 2010. 
Soerjono Soekanto, Efektivitas Hukum dan Peranan Sanksi, Cetakan pertama, Remaja Karya CV Bandung 1985.

-, Pengantar Penelitian Hukum,Ul Press, Jakarta, 1986.

Tim Peneliti Fakultas Hukum UGM, Pengaturan Mata Uang Republik Indonesia, Buletin Hukum Perbankan dan Kebanksentralan, Volume 4 Nomor 1, April 2006.

\section{Perundang-Undangan :}

Kitab Undang-Undang Hukum Pidana (KUHP)

Undang-Undang Dasar 1945

Undang-undang No.7 Tahun 2011 Tentang Mata Uang.

Undang-undang No.23 Tahun 1999 Tentang Bank Indonesia.

Undang-Undang Darurat Nomor 20 Tahun 1951 Tentang Penghentian Berlakunya "Indische Muntwet 1912" dan Penetapan Peraturan Baru tentang Mata Uang.

Undang-Undang Nomor 27 Tahun 1953 Tentang Penetapan "UndangUndang Darurat Tentang Penghentian Berlakunya "Indische Muntwet 1912" dan Penetapan Peraturan Baru tentang Mata Uang (Undang-Undang Darurat Nomor 20 Tahun 1951) Sebagai Undang-Undang.

Undang-Undang Darurat Nomor 4 Tahun 1958 tentang Pengubahan "Undang-Undang Mata Uang Tahun 1953".

UndangUndang Nomor 71 Tahun 1958 Tentang Penetapan "Undang-Undang Darurat Nomor 4 Tahun 1958 Tentang Pengubahan Undang-Undang Mata Uang Tahun 1953" Sebagai Undang-Undang.

\section{Wawancara}

Hasil Wawancara Dengan, Daeng Sain. Salah seorang pedagang Di Maluku Tenggah, Desa Morella, Kecamatan Leihitu, 28 September 2017, pukul 10:30 WIT.

Hasil Wawancara Dengan Bapak Hujianto, Pegawai Bank Indonesia Kantor Perwakilan Maluku Staf Bagian Unit Pengawasan Sistem Pembayaran, Pengelolaan Uang Rupiah dan Keuangan inklusif (unit pengawasan sp,pur dan ki) yang diwawancarai pada tanggal 28 september 2017 Pukul 14:30 WIT di kantor Bank Indonesia Perwakilan Maluku.

Hasil wawancara dengan Bapak Richard S Tupamahu, Jabatan Ba Sat Reskrim, Kesatuan Polres Pulau Ambon dan Pulau-pulau Lease pada hari Senin 16 Oktober 2017, Pukul 13:30 WIT, Di Kantor Sat Reskrim Polres Pulau Ambon dan Pulau-pulau Lease.

\section{Lain-lain}

http://www.bi.go.id/id/sistem-pembayaran/instrumen/datauang/Contents/Default.aspx/ http://www.bi.go.id/id/sistem-pembayaran/instrumen/uang-yangdicabut/Contents/Default.aspx/ 